\title{
Favorable Glycemic Control with Once-Daily Insulin Degludec/Insulin Aspart after Changing from Basal Insulin in Adults with Type 2 Diabetes (Endocrinol Metab 2019; 34:382-9, Han Na Jang et al.)
}

Han Na Jang, Hye Seung Jung

Division of Endocrinology and Metabolism, Department of Internal Medicine, Seoul National University Hospital, Seoul

National University College of Medicine, Seoul, Korea

Thank you so much for your interest in our paper and for your insightful comments on it. Our paper suggests that once-daily insulin degludec/insulin aspart (IDegAsp) can control blood glucose levels better than once-daily basal insulin, especially for patients with severe insulin deficiency and high blood glucose variation [1].

As you pointed out, this study has the limitations of a retrospective design, a small number of patients, and a short followup duration. Therefore, we acknowledge that the conclusions of this study are not fully definitive; instead, we interpret the results as suggesting the need to conduct further research to identify an indicator of the subset of patients who obtain more benefits by changing from basal insulin to IDegAsp. This would be a significant advance because IDegAsp has failed to demonstrate superiority to basal insulin in the broader population of insulindependent patients with diabetes. Based on this pilot study, we are planning to perform a randomized controlled trial comparing IDegAsp to basal insulin in patients with a high gap between the predicted fasting plasma glucose (FPG) level and the measured FPG. With concurrent analysis using continuous glucose monitors, we expect to elucidate the relationship between the effects of IDegAsp and glycemic variability in this upcoming

Received: 18 February 2020, Accepted: 21 February 2020

Corresponding author: Hye Seung Jung

Department of Internal Medicine, Seoul National University Hospital, Seoul National University College of Medicine, 101 Daehak-ro, Jongno-gu, Seoul 03080, Korea

Tel: +82-2-2072-0240, Fax: +82-2-764-2199, Email: junghs@snu.ac.kr study. As you pointed out, precise measurements of the gap between predicted and measured FPG should be performed in a large cohort.

As you mentioned, GLP-1 agonists are beneficial for postprandial blood glucose control and have a cardiovascular protective effect [2], so the use of a combination of basal insulin and a GLP-1 agonist can effectively control postprandial blood glucose and obtain cardiovascular protective effects without increasing the number of injections [3]. However, there are still patients in whom it is difficult to use a GLP-1 agonist due to a low glomerular filtration rate or adverse effects such as gastrointestinal troubles [2]. Most of all, the eventual failure of GLP-1 therapy leads to multiple daily insulin injections, which would involve a mixed regimen such as IDegAsp [4].

Thank you again for your comments on our paper. If you have any other comments or questions, please feel free to contact me.

\section{CONFLICTS OF INTEREST}

No potential conflict of interest relevant to this article was reported.
Copyright $(2020$ Korean Endocrine Society

This is an Open Access article distributed under the terms of the Creative Commons Attribution Non-Commercial License (https://creativecommons.org/ licenses/by-nc/4.0/) which permits unrestricted non-commercial use, distribution, and reproduction in any medium, provided the original work is properly cited. 


\section{ORCID}

Han Na Jang https://orcid.org/0000-0002-6186-2937

Hye Seung Jung https://orcid.org/0000-0002-0221-7049

\section{REFERENCES}

1. Jang HN, Yang YS, Lee SO, Oh TJ, Koo BK, Jung HS. Favorable glycemic control with once-daily insulin degludec/ insulin aspart after changing from basal insulin in adults with type 2 diabetes. Endocrinol Metab (Seoul) 2019;34: 382-9.
2. Prasad-Reddy L, Isaacs D. A clinical review of GLP-1 receptor agonists: efficacy and safety in diabetes and beyond. Drugs Context 2015;4:212283.

3. Rosenstock J, Aronson R, Grunberger G, Hanefeld M, Piatti $\mathrm{P}$, Serusclat $\mathrm{P}$, et al. Benefits of lixilan, a titratable fixed-ratio combination of insulin glargine plus lixisenatide, versus insulin glargine and lixisenatide monocomponents in type 2 diabetes inadequately controlled on oral agents: The LixiLan-O Randomized Trial. Diabetes Care 2016;39:2026-35.

4. American Diabetes Association. 9. Pharmacologic approaches to glycemic treatment: standards of medical care in diabetes-2020. Diabetes Care 2020;43(Suppl 1):S98-110. 